
disappointment.

Of course, research in the field can only benefit from the emphasis on quality in the long term - the editors' aim in this respect will, I hope, not suffer from 'enhanced degradation' when attracting manuscripts.

At a time when new journals often induce yawns of indifference I can for

\section{Causes and cures}

\section{Michael L. Berrow}

Land Degradation and Rehabilitation. Editor-in-chief C. J. Barrow. Wiley. 4/yr. $\$ 150$ (institutional); $\$ 112.50, \mathbf{1 6 3 . 7 5}$ (personal).

THERE is now much concern about the worldwide degradation of land and the accompanying reduction in ecosystem diversity. We are all made increasingly aware of problems such as desertification, erosion, deforestation, storms and flooding that affect many developing countries, whereas the effects of atmospheric pollution, mining, urbanization, sewage disposal, industrial effluents and acid rain in the more industrialized countries confront us daily. It is opportune, therefore, that a new journal addressing these serious problems in a global context has been launched.

The first issue of Land Degradation and Rehabilitation appeared in July 1989. Its aims and scope embrace a wide range of topics, including environments, processes, causes, perception, impacts and management, related to land degradation. The interdisciplinary and international content is well illustrated by the first six issues, which include informative contributions from the six continents. These cover topics as diverse time-consuming refereeing could cause

once express a sight of relief: Biodegradation not only fills a definite niche but does it admirably. I look forward to an expanding number of annual issues as the journal becomes established and accepted.

W. B. Betts is in the Institute for Applied Biology, University of York, Heslington, York YO1 5DD, UK.

as soil erosion by wind and water, flooding, deforestation, compaction, salinization, effects of mining activities, revegetation using grasses or trees, remote sensing applied to derelict land, soil degradation, soil conservation, sustainable agriculture, rural development, climate change, economic development and population-resource projections. Each issue contains related book reviews.

There is a good balance of papers dealing with the problems of developed and developing countries, with about one-third of the first 34 papers reporting work in Africa and China and another third work in Europe and North America. A strength of the journal is that, as well as seeking to identify and quantify causes, it emphasizes measures to avoid, control or manage the harmful effects of degradation.

The editors stress that good data are essential for policy formulation and decision making. A plea is made for the use of statistical design in experimentation and for a considerable improvement in the quality of environmental data, even allowing for the many difficulties that arise in carrying out field research in developing countries. Judging by the quality of papers in the early issues, this challenge is being met.

Michael L. Berrow is in the Division of Soils and Soil Microbiology, Macaulay Land Use Research Institute, Craigiebuckler, Aberdeen, Scotland AB9 2QJ, UK.

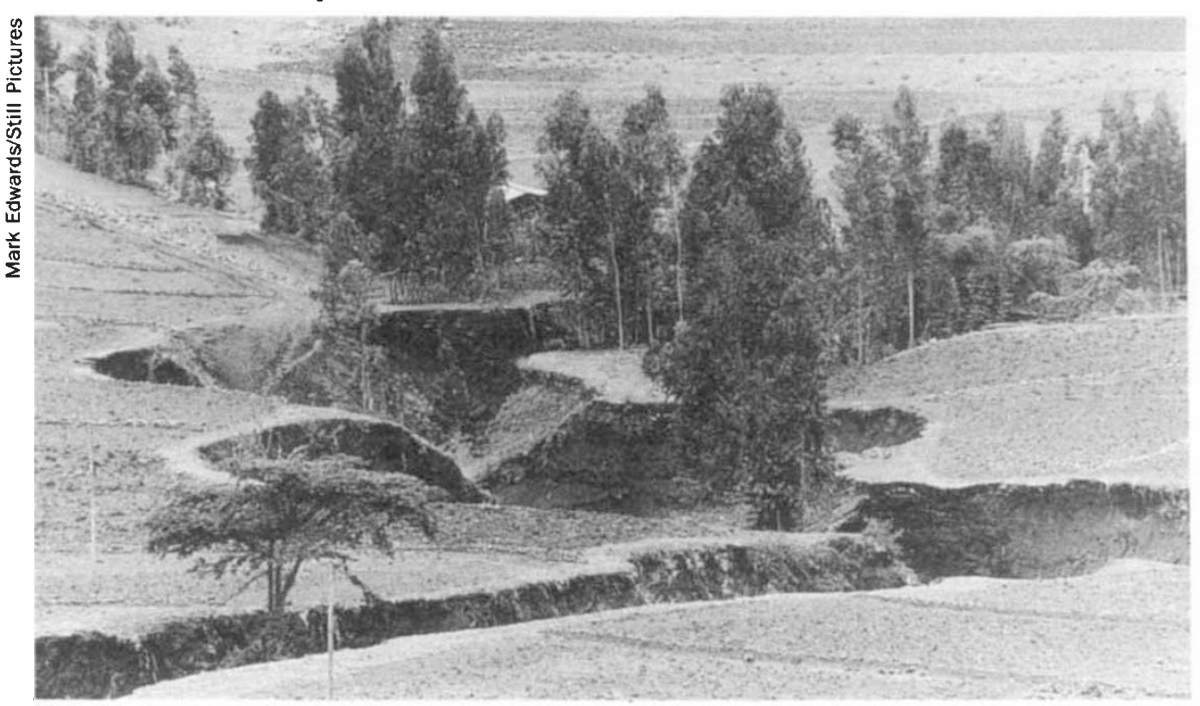

Massive land erosion in Ethiopia caused by deforestation.

\section{Also submitted for review}

The following is a list of journals that were eligible for review but that for one reason or another are not covered in the preceding pages. The list does not include journals sent to us that had not published enough titles to be considered.

Accounts and Rapid Communications in Synthetic Organic Chemistry (Georg Thieme Verlag)

Advances in Physiology Education (The

American Physiological Society)

Biotechnology Education (Pergamon)

Blood Coagulation and Fibrinolysis

(Rapid Communications of Oxford)

Chemoecology (Georg Thieme Verlag)

Chemtracts: Biochemistry and Molecular Biology (Data Trace Chemistry Publishers)

Comments on Developmental Neurobiology (Bell and Bain)

Current Opinion in Biotechnology (Current Biology)

Current Opinion in Lipidology (Current Science)

European Journal of Applied Mathematics (Cambridge University Press)

European Journal of Cancer (Pergamon)

Expert Systems with Applications (Pergamon)

Immunology and Infectious Diseases (Rapid Communications of Oxford)

International Journal of Modern Physics $C$ (World Scientific)

Journal of Educational and Psychological Consultation (Erlbaum)

Journal of Electronic Testing: Theory and Applications (Kluwer)

Journal of Wilderness Medicine (Chapman and Hall Medical)

Land Management and Environmental Law Report (SLE Publications)

Language Acquisition: A Journal of Developmental Linguistics (Erlbaum)

Lithium (Churchill Livingstone)

Mathematics Review (Philip Allan)

Multidimensional Systems and Signal Processing (Kluwer)

Pesticide Outlook (Royal School of Chemistry)

Platelets (Churchill Livingstone)

Polar and Glaciological Abstracts (Cambridge University Press)

Psychological Inquiry (Erlbaum)

Receptor (Humana)

Restorative Neurology and Neuroscience (Elsevier)

Scientific Drilling (Springer International)

Structural Optimization (Springer)

\section{Autumn Books}

Nature's next review supplement will be Autumn Books, which will appear in the 28 November issue. 